\title{
Inherited disorders of 3-methylcrotonyl CoA carboxylation
}

\author{
J V LEONARD, J W T SEAKINS, K BARTLETT, J HYDE, J WILSON, AND \\ BARBARA CLAYTON
}

Department of Child Health and Department of Chemical Pathology, Institute of Child Health, London, Department of Neurology, The Hospital for Sick Children, London, and Department of Clinical Biochemistry, Royal Victoria Infirmary, Newcastle-upon-Tyne

SUMMARY The clinical course of 4 patients who had reduced activities of 3-methylcrotonyl CoA carboxylase (also called 3-methylcrotonylglycinuria) is described. Two children presented with a metabolic acidosis, one in the neonatal period and the other with episodes of acidosis that started in the second year of life. In the other 2 children neurological symptoms were prominent, one having infantile spasms and the other developmental regression with a skin rash and alopecia. Three of the children responded well to oral biotin and dietary protein restriction but the fourth, despite a biochemical response to biotin, has a severe neurological handicap. The clinical presentation of inborn errors of 3-methylcrotonyl CoA carboxylase is variable. Metabolic acidosis may not be conspicuous and instead neurological features may predominate.

Inborn errors of all the enzymes of leucine degradation have now been described (Fig. 1) including maple syrup urine disease and isovaleric acidaemia. The deficiency of 3-methylcrotonyl CoA carboxylase (also called 3-methylcrotonylglycinuria, see Fig. 1) was first described by Eldjarn et al. in $1970^{1}$ and since then 8 more patients have been reported. ${ }^{2-9}$ The first child presented with feeding difficulties, developmental delay, and a neurological syndrome similar to spinal muscular atrophy but the clinical

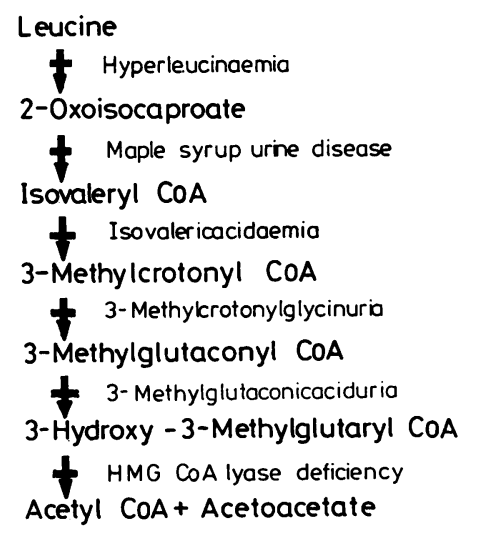

Fig. 1 Inborn errors of leucine catabolism. and the biochemical findings of subsequent patients have varied considerably. Most patients have presented during the first year of life. Although this condition is a disorder of organic acid metabolism, metabolic acidosis is not always a conspicuous feature and instead neurological features may predominate. In this paper we describe the clinical and biochemical findings in 4 further children which emphasise the clinical spectrum that may be seen in this condition.

\section{Methods}

Gas-liquid chromatography of organic acids. Extraction and formation of derivatives of the nonvolatile organic acids was performed by methods that have been described previously, with some minor modifications. ${ }^{10}$

Enzyme determination. Fibroblasts were cultured in minimum Eagle's medium containing $10 \%$ fetal calf serum and Hanks's salts in $80 \mathrm{~cm}^{3}$ Nunc flasks. The medium contains only that biotin provided by the fetal calf serum. Cells were also grown in the presence of $1 \mathrm{mg} / 1$ added biotin. Cells from confluent cultures were harvested by trypsinisation and washed twice in sodium bicarbonate buffered Hanks's balanced salt solution. 


\section{Leonard, Seakins, Bartlett, Hyde, Wilson, and Clayton}

Cell pellets were homogenised by sonication in $500 \mu \mathrm{l} 5 \mathrm{mmol} / \mathrm{l}$ phosphate buffer (pH 7). Propionyl $\mathrm{CoA}$, 3-methylcrotonyl $\mathrm{CoA}$, and pyruvate carboxylase were measured by a substrate-dependent ${ }^{14} \mathrm{CO}_{2}$ fixation assay. ${ }^{11-12}$ The pyruvate carboxylase assay mixture included $0.27 \mathrm{mmol} / \mathrm{l}$ acetyl CoA, which is an allosteric activator of this enzyme. The products of the reaction were largely malate and citrate. All three carboxylase assays were linear with respect to time and protein concentration and were measured under $\mathrm{V}_{\max }$ conditions. Protein concentrations were estimated by the method of Lowry et al. ${ }^{13}$

\section{Case reports}

Case 1. This girl was born on 27 March 1977, the second child of unrelated English parents. She had been born 8 days past term by caesarean section for fetal distress during labour. At birth she had weighed $2.93 \mathrm{~kg}$ and had been in good condition. Initially she fed well on a 'humanised' milk but at 51 hours she was tachypnoeic, hypothermic $\left(35^{\circ} 5^{\circ} \mathrm{C}\right)$, floppy, and reluctant to feed. A screen for infection and one for blood sugar were normal, but there was a metabolic acidosis (pH 7.04, $\mathrm{PCO}_{2} 23 \mathrm{mmHg}$ $(3.07 \mathrm{kPa})$, base excess $-22 \mathrm{mmol} / \mathrm{l})$, and the blood lactate level $(4.8 \mathrm{mmol} / 1 ; 43 \mathrm{mg} / 100 \mathrm{ml})$ was raised. She was started on antibiotics and sodium bicarbonate, but her acid-base status did not improve and, as her condition was deteriorating, she was transferred to The Hospital for Sick Children, London.

On admission at 69 hours she lay quietly with rapid and deep sighing respirations, but was jittery on being disturbed. Her muscle tone was normal. Arterial blood gases were $\mathrm{pH} 7 \cdot 04, \mathrm{PCO}_{2} 21 \mathrm{mmHg}$ $(2 \cdot 8 \mathrm{kPa})$, base excess $-26 \mathrm{mmol} / \mathrm{l}$. Plasma aminoacids showed raised levels of the branch chain aminoacids (leucine $650 \mu \mathrm{mol} / 1(8.5 \mathrm{mg} / 100 \mathrm{ml})$, isoleucine $200 \mu \mathrm{mol} / 1(2.6 \mathrm{mg} / 100 \mathrm{ml})$, valine $350 \mu \mathrm{mol} / \mathrm{l}(4 \cdot 1$ $\mathrm{mg} / 100 \mathrm{ml})$ ) with slightly increased alanine levels, but the remainder of the pattern was normal.
She was initially thought to have maple syrup urine disease and was treated with glucose and sodium bicarbonate intravenously, and a glucose polymer and synthetic amino-acid mixture that omitted the branch chain amino-acids by mouth. She was also started empirically on biotin $10 \mathrm{mg}$ and thiamine $20 \mathrm{mg}$ daily.

The correct diagnosis was made by gas-liquid chromatography of the urine organic acids which showed the presence of a gross excess of 3-hydroxyisovalerate (3HIVA, about $5 \mathrm{mmol} / \mathrm{mmol}$ creatinine) and 3-hydroxybutyrate, but 3-methylcrotonylglycine (3MCG) was not detected. Oral biotin was continued and the protein content of her diet was slowly increased from $0.5 \mathrm{~g} / \mathrm{kg}$ to $3 \mathrm{~g} / \mathrm{kg}$ a day. On this regimen she fed well, gained weight, and behaved normally. After 4 weeks in hospital the organic acid pattern in her urine was normal. At age 6 months her protein intake was increased to $5 \mathrm{~g} / \mathrm{kg}$ a day but within 24 hours she had become acidotic with metabolites in the urine. Since then she has continued on a protein intake of $2.5 \mathrm{~g} / \mathrm{kg}$ a day and has thrived. At age 3 years her development is normal. Measurement of the activity of 3-methylcrotonyl CoA carboxylase activity in cultured fibroblasts showed lack of activity, and there was no improvement when the cells were cultured in additional biotin. The activity of propionyl CoA carboxylase was lower than that of controls (Table 1).

Case 2. This girl was born on 2 November 1972, the second child of healthy but consanguineouslyrelated Pakistani parents. She had been born normally at term weighing $2.84 \mathrm{~kg}$ and had progressed normally until the onset of typical salaam spasms at one month. After a few days she started to have generalised convulsions and, when admitted to a local paediatric unit shortly afterwards, she was found to be acidotic with raised plasma concentrations of pyruvate $(238-300 \mu \mathrm{mol} / 1(2 \cdot 1-2 \cdot 6 \mathrm{mg} /$ $100 \mathrm{ml})$ normal $<100 \mu \mathrm{mol} / 1(0.9 \mathrm{mg} / 100 \mathrm{ml}))$, and

Table 1 Fibroblast carboxylase activities in patients with disorders of 3-methylcrotonyl CoA carboxylation (nmol/h per mg protein)

\begin{tabular}{|c|c|c|c|c|c|c|c|}
\hline \multirow[t]{2}{*}{ Case } & \multirow{2}{*}{$\begin{array}{l}\text { Clinical response } \\
\text { to biotin }\end{array}$} & \multicolumn{2}{|c|}{ Propionyl CoA carboxylase } & \multicolumn{2}{|c|}{ 3-Methylcrotonyl CoA carboxylase } & \multicolumn{2}{|c|}{ Pyruvate carboxylase } \\
\hline & & $\begin{array}{l}\text { No additional } \\
\text { biotin }\end{array}$ & $\begin{array}{l}\text { Plus } \\
\text { biotin }\end{array}$ & $\begin{array}{l}\text { No additional } \\
\text { biotin }\end{array}$ & $\begin{array}{l}\text { Plus } \\
\text { biotin }\end{array}$ & $\begin{array}{l}\text { No additional } \\
\text { biotin }\end{array}$ & $\begin{array}{l}\text { Plus } \\
\text { biotin }\end{array}$ \\
\hline $\begin{array}{l}1 \\
2\end{array}$ & $\frac{ \pm}{+}$ & $1 \cdot 8$ & \multicolumn{3}{|c|}{ No enzyme results available } & NA & NA \\
\hline $\begin{array}{l}3 \\
4\end{array}$ & $\begin{array}{l}+ \\
+\end{array}$ & $\begin{array}{r}9.8 \\
30 \cdot 9\end{array}$ & $\begin{array}{l}58 \cdot 4 \\
30 \cdot 8\end{array}$ & $\begin{array}{r}0.9 \\
15.6\end{array}$ & $\begin{array}{l}13 \cdot 2 \\
14 \cdot 5\end{array}$ & $\begin{array}{l}2 \cdot 4 \\
\text { NA }\end{array}$ & $\begin{array}{l}12 \cdot 6 \\
\text { NA }\end{array}$ \\
\hline Normal values $(n=11)$ & $\begin{array}{l}\text { Mean } \\
\text { SD } \\
\text { Range }\end{array}$ & $\begin{array}{l}45 \cdot 0 \\
25 \cdot 4 \\
13 \cdot 7-96 \cdot 5\end{array}$ & & $\begin{array}{l}13 \cdot 6 \\
6 \cdot 0 \\
4 \cdot 7-23.2\end{array}$ & & $\begin{array}{l}15 \cdot 2 \\
7 \cdot 6 \\
10 \cdot 1-31 \cdot 4\end{array}$ & \\
\hline
\end{tabular}

NA $=$ Not assayed. 
lactate $(3 \cdot 5-4 \cdot 2 \mathrm{mmol} / \mathrm{l}(31 \cdot 5-37 \cdot 8 \mathrm{mg} / 100 \mathrm{ml})$, normal $<1 \cdot 8 \mathrm{mmol} / 1(16 \cdot 2 \mathrm{mg} / 100 \mathrm{ml}))$. At 10 weeks she was transferred to The Hospital for Sick Children; she was mildly tachypnoeic but not ill. Although floppy, the tendon reflexes were exaggerated and she was inactive and unresponsive. Her head circumference was $40 \cdot 2 \mathrm{~cm}$ (50th centile) and she weighed $5.07 \mathrm{~kg}$ (50th centile). During the next month she developed athetoid movements and became hypertonic with opisthotonic posturing. She remained inattentive to visual stimuli and had frequent extensor spasms, major fits being controlled with phenytoin. Blood gases confirmed a consistent mild metabolic acidosis $\left(\mathrm{pH} 7 \cdot 33, \mathrm{PCO}_{2} 30 \mathrm{mmHg}(4.0 \mathrm{kPa})\right.$, base excess $-5 \mathrm{mmol} / \mathrm{l})$, with raised plasma pyruvate $(140-187 \mu \mathrm{mol} / \mathrm{l}(1 \cdot 2-1 \cdot 65 \mathrm{mg} / 100 \mathrm{ml}))$ and lactate levels $(2.6 \mathrm{mmol} / 1(23.4 \mathrm{mg} / 100 \mathrm{ml}))$.

Blood and urine amino-acids were normal. An electroencephalogram showed a gross abnormality and lack of usual rhythmic activity, with multifocal discharges and periods of diminished activity. Air encephalography demonstrated cerebral atrophy. Gas-liquid chromatography of organic acids in the urine showed a gross excess of 3HIVA and lactate. After starting biotin ( $5 \mathrm{mg}$ daily orally), there was considerable improvement. The abnormal organic acids disappeared from the urine and she became more responsive and less hypertonic. The fits stopped. During the next 3 months she started to smile at her parents and showed better head control. Tendon reflexes became normal.

At age $5 \frac{3}{4}$ years she has a spastic diplegia but is able to walk with help although not on her own. She has no recognisable speech but is able to understand simple commands. No enzyme measurements have been made because a fibroblast culture failed to grow and the family have refused further skin biopsies.

Case 3. This girl was born on 7 November 1973, the third child of unrelated Iraqi parents. She had been born at term weighing $3.86 \mathrm{~kg}$, and there had been no perinatal problems. She was breast fed for 9 months with supplements from age 3 months. At age 14 months, during a mild febrile illness with coryza, she developed pronounced respiratory distress and became comatose. Investigations showed a metabolic acidosis which was treated with intravenous sodium bicarbonate. She made an uneventful recovery and one year later had measles without complications. At the age of $3 \frac{1}{4}$ years she again developed a metabolic acidosis $\left(\mathrm{pH} 7 \cdot 16, \mathrm{PCO}_{2}\right.$ $13.6 \mathrm{mmHg}(1.8 \mathrm{kPa})$, base excess $-20 \mathrm{mmol} / \mathrm{l})$ during a mild upper respiratory tract infection with some vomiting. She made an uneventful recovery after treatment with sodium bicarbonate. She was first seen at The Hospita! for Sick Children at age $4 \frac{1}{4}$ years when she was a healthy well-grown child of normal intelligence (height $106.7 \mathrm{~cm}$, weight $17 \mathrm{~kg}$ ). She was eating a self-selected low-protein diet but despite this she had a mild metabolic acidosis $\left(\mathrm{pH} 7 \cdot 23, \mathrm{PCO}_{2} 42 \mathrm{mmHg}(5 \cdot 6 \mathrm{kPa})\right.$, base excess $-10.3 \mathrm{mmol} / \mathrm{l})$. Urine and plasma aminoacids were normal. Gas-liquid chromatography of the urine showed the presence of 3HIVA $(0.42$ $\mathrm{mmol} / \mathrm{mmol}$ creatinine) and $3 \mathrm{MCG}(0.25 \mathrm{mmol} /$ mmol creatinine). After treatment with oral biotin ( $5 \mathrm{mg}$ daily) for 10 days the abnormal metabolites disappeared. She was discharged on oral biotin and advised to continue the low-protein diet. When seen 6 months later she had remained well and had had chicken pox uneventfully. She had developed a liking for protein and had increased her protein intake to about $3.6 \mathrm{~g} / \mathrm{kg}$ a day. On this diet the metabolites were present in the urine and she was advised to reduce her protein intake to $2 \mathrm{~g} / \mathrm{kg}$ a day. The child can no longer be followed up as the family has returned to the Middle East.

The results of the enzyme studies show that she has a defect of three biotin-dependent carboxylases-3-methylcrotonyl CoA carboxylase, propionyl CoA carboxylase, and pyruvate carboxylase. In the presence of biotin the activity of these enzymes was restored to normal (Table 1). More details have been reported elsewhere. ${ }^{20}$

Case 4. This girl was born on 31 October 1976, the third child of parents of Scottish tinker stock who were 2 nd cousins. Their second child, a girl, had died at age 22 months without a diagnosis being made. The history of her illness was almost identical with that of the patient. The patient had been born normally after an uneventful pregnancy lasting about 37 weeks. She weighed $3.35 \mathrm{~kg}$. During the first feed she had two cyanotic spells but there had been no other perinatal problems.

She had thrived until age 6 months when she developed 'heavy breathing' but was otherwise well. At age 1 year her developmental progress was normal but she started to have episodes of shaking of the hands associated with stridor. She did not lose consciousness. These attacks became more frequent and her respirations more laboured, being aggravated by intercurrent infections.

Her hair became sparse. At age 14 months she developed otitis media and was admitted to hospital tachypnoeic and cyanosed. She had a metabolic acidosis which was treated with sodium bicarbonate. After this admission she started to regress developmentally. At 19 months, when first admitted to The 
Hospital for Sick Children, she was a miserable child with sparse hair and an eczematous rash around her nose and mouth. She was $83 \mathrm{~cm}$ in length (50-75th centile) and weighed $9.95 \mathrm{~kg}$ (3-10th centile). She had inspiratory stridor and the liver was enlarged $5 \mathrm{~cm}$ below the costal margin. She was hypotonic but her tendon reflexes were brisk. There was optic atrophy. It was difficult to assess her developmental level because of the neuromuscular problems but she appeared to have regressed to below the 6-month-old level.

Investigations showed a compensated metabolic acidosis $\left(\mathrm{pH} 7 \cdot 36, \mathrm{PCO}_{2} 13.2 \mathrm{mmHg}(1.8 \mathrm{kPa})\right.$, base excess $-14.8 \mathrm{mmol} / \mathrm{l})$. The blood lactate was $8 \mathrm{mmol} / 1(72.0 \mathrm{mg} / 100 \mathrm{ml})$ and pyruvate $417 \mu \mathrm{mol} / 1$ $(3.7 \mathrm{mg} / 100 \mathrm{ml})$. Plasma amino-acids were normal but there was increased excretion of alanine and glycine in the urine. Gas-liquid chromatography of the urine organic acids showed the gross excretion of lactate, 3HIVA, 3MCG, and 2-methylcrotonylglycine. Electroencephalograms showed a diffuse abnormality with excess slow-wave activity but there were no paroxysmal features. The electroretinogram was normal but there was no recognisable cortical response to photic stimulation. She was started on a low-protein diet $(1.5 \mathrm{~g} / \mathrm{kg}$ a day) with biotin $10 \mathrm{mg}$ daily, and there was a remarkable improvement. The rash healed and she made rapid developmental progress regaining milestones she had lost. The metabolic acidosis disappeared and within 10 days none of the abnormal metabolites could be detected in the urine. By age 23 months the developmental quotient on the Griffiths's scale was 13 months, with a range of subscores of between 10 and 18 months, but 3 months later the range had improved to between 17 and 24 months. Since the start of dietary treatment with biotin she has remained well but attempts to liberalise the diet have not been successful. Characteristic metabolites reappeared in the urine when the dietary protein was increased to $2 \mathrm{~g} / \mathrm{kg}$ a day and during intercurrent infection. The activity of 3-methylcrotonyl CoA carboxylase in cultured fibroblasts was normal (Table 1).

\section{Discussion}

The patients who have been described with deficiency of 3-methylcrotonyl CoA carboxylase are listed in Table 2. Most of them presented in the first year of life but the clinical features have varied. Only 2 patients have presented in the neonatal period with severe metabolic acidosis and in 5 infants the acidosis was absent or mild (base deficit $<7.5$ $\mathrm{mmol} / \mathrm{l})$. Six patients have presented with predominantly neurological features: 3 as floppy babies

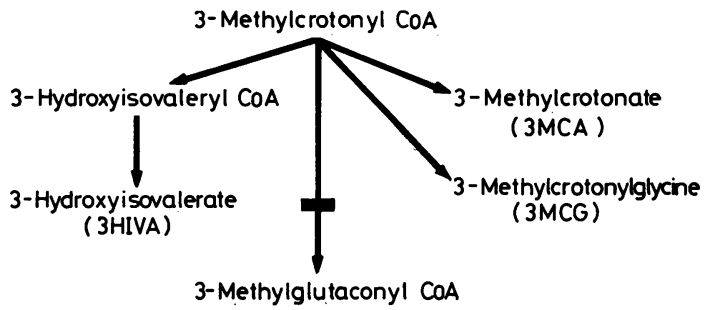

Fig. 2 Metabolites formed as a result of the accumulation of 3-methylcrotonyl CoA.

with developmental regression, 2 with infantile spasms, and 1 with generalised convulsions. The diagnosis of 3-methylcrotonyl CoA carboxylase deficiency was initially made on the basis of the organic acids excreted in the urine. These are derived from the 3-methylcrotonyl CoA which accumulates and can be metabolised in three ways (Fig. 2). It can be conjugated with glycine to form 3-methylcrotonylglycine. 3-Hydroxyisovalerate is formed by the action of enoyl hydratase and subsequent hydrolysis of thioester. Direct hydrolysis of the 3-methylcrotonyl CoA also occurs to a limited extent. The pattern of the organic acids excreted in the urine will be determined by the relative activities of these enzymes, their affinity for the substrate, and the availability of glycine. In most patients (Cases 3, 4, $5-7,9-12$ ) the concentrations of 3MCG (or 3MCA) and 3HIVA were greatly raised, but in Cases 1, 2, 8 , and 13 only 3 HIVA was detected. Potentially the presence of this acid alone could cause diagnostic difficulties as this metabolite is excreted in similar concentrations in keto-acidosis ${ }^{14}$ and also in combination with other organic acids in isovalericacidaemia ${ }^{15}$ and 3-hydroxy-3-methylglutaric aciduria. ${ }^{16-17}$ Thus the diagnosis should be confirmed by measuring the activity of the 3-methylcrotonyl CoA carboxylase. In 2 children in whom the enzyme was measured who excreted only 3HIVA, the activity of this enzyme was low.

Facilities for detecting organic acids are not widely available, so the diagnosis is often delayed (Table 2). The presence of a metabolic acidosis is often a useful clue to the possibility of an organic acidaemia but in only 6 of these cases was the metabolic acidosis (base deficit $>10 \mathrm{mmol} / \mathrm{l}$ ) sufficient to suggest the possibility of an organic acidaemia. Furthermore blood and urine lactate levels are often raised in the acute phase of this condition (Cases 2, 4, 9, 10,11,12, and 13), and as a result the acidosis may be attributed wholly to lactic acidosis, no measurement of the organic acids being made. Plasma and urine amino-acids are generally normal although mildly raised branch 


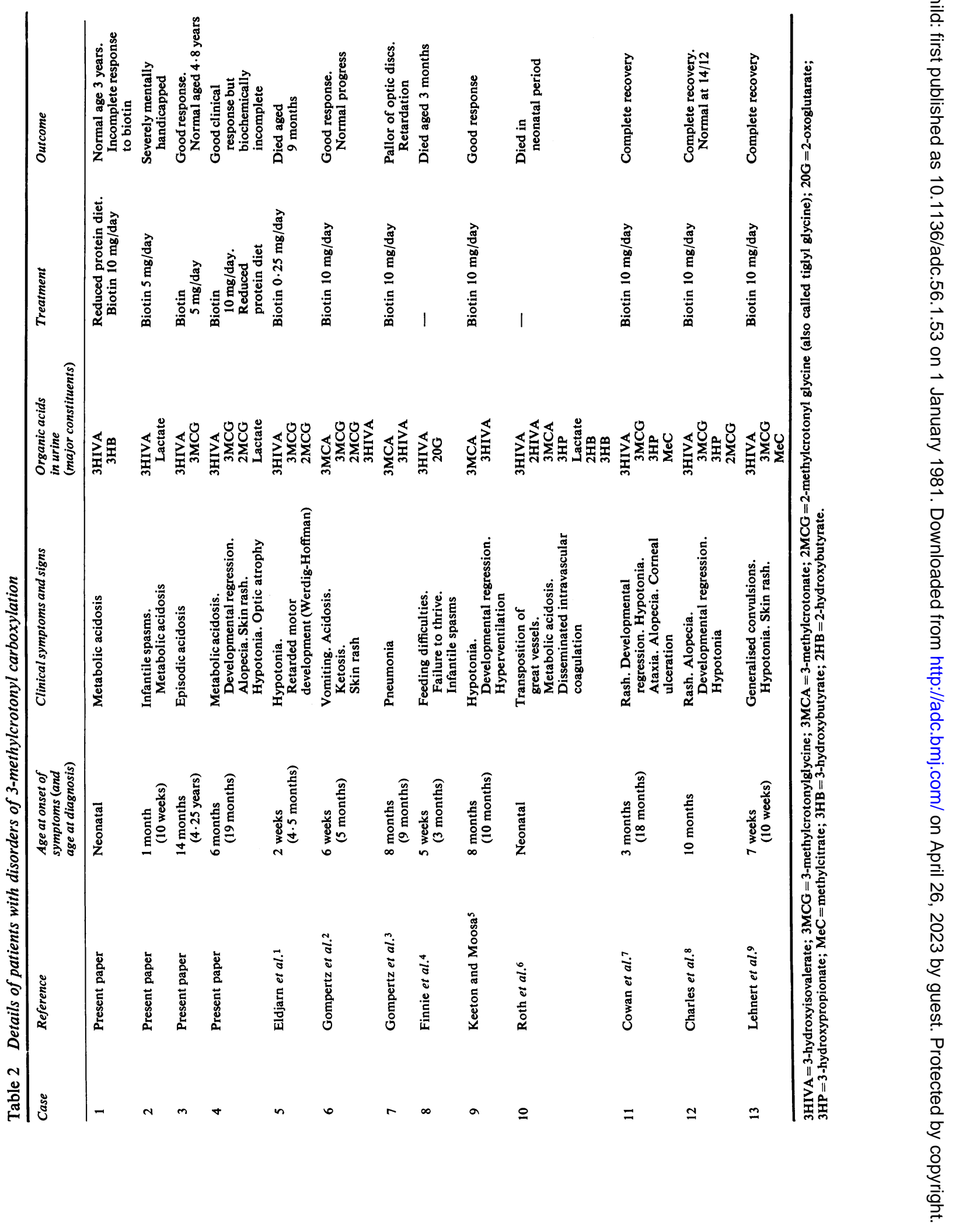


chain levels were seen in 2 patients (Cases 1 and 9). Amino-acid concentrations are of little value in screening for this disorder and normal levels do not exclude the diagnosis which can be made only by examining the urinary organic acids. As there are no specific physical signs, and conventional laboratory tests are often unhelpful, clinicians need to be aware of the possibility of an organic acidaemia. If there is any suspicion, examination of organic acids in the urine by gas-liquid chromatography should be requested.

The condition does not have a single biochemical basis and this is reflected in the clinical heterogeneity. Biotin-dependent carboxylases are synthesised from the respective apoenzymes by the action of holocarboxylase synthetase (Fig. 3). Thus a defect of the synthetase, biotin availability, or the apoenzyme could cause decreased holocarboxylase activity. One child (Case 1) was clinically responsive only to a partial extent to biotin and had complete lack of enzyme activity in cultured fibroblasts. There was no increase in activity when the cells were cultured in the presence of additional biotin. But in other patients (Cases 3, 6, and 11) there was almost certainly a defect in biotin metabolism because the patients had defects of more than one biotin-dependent enzyme and the activity of these enzymes was restored to normal with additional biotin in the culture medium. Clinically all responded well to large doses of oral biotin. Three patients (Cases 4, 11, and 12) have been described with the combination of alopecia, skin rash, hypotonia, and developmental regression. They have all responded strikingly to oral biotin. Alopecia and skin rash are symptoms of systematic biotin deficiency ${ }^{18-19}$ and it has been suggested that these patients have a more generalised abnormality of biotin metabolism, possibly a defect in biotin transport. In the 2 patients in whom 3-methylcrotonyl CoA carboxylase activity was measured it was normal. It has been suggested that either the defect is not expressed in fibroblasts or that the biotin present in the fetal calf serum,

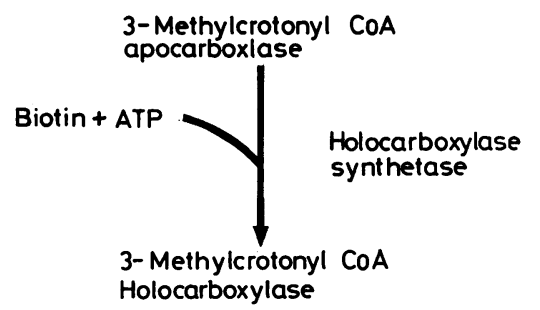

Fig. 3 Synthesis of 3-methylcrotonyl CoA holocarboxylase from biotin and the apoenzyme. which is essential for normal growth, restored the enzyme activity to normal.

Three of the patients died and in addition siblings died too without a diagnosis being made. The outcome of the survivors is poorly documented. The patient described by Gompertz et al. ${ }^{2}$ (Case 6) who was fully biotin-responsive has been followed up in this hospital and is now aged 9 years. He has grown and developed normally and since starting biotin $10 \mathrm{mg}$ daily he has no metabolites in the urine and no episodes of metabolic acidosis with intercurrent infections. Cases 1 and 3 (aged 3 and 5 years) are growing and developing normally but Case 2 who had infantile spasms is severely mentally retarded. Case $\mathbf{4}$ has made good developmental progress after the administration of biotin and is now close to the normal level for her age. Thus the prognosis for both biotin and nonbiotin-responsive forms is generally good, provided the diagnosis is made early.

\section{Addendum}

Since the paper was accepted a 2nd-cousin of Case 4 presented with convulsions and later developed alopecia, blepharitis, and a skin rash. He had multiple carboxylase deficiency and responded to oral biotin. In addition several more children with multiple carboxylase deficiency have been described. ${ }^{21-23}$

We thank Dr D G H Stone, Dr P D Moss, and Dr Valerie Marrian for referring the patients to us.

The Rank Group Charity provided financial support.

\section{References}

1 Eldjarn L, Jellum E, Stokke O, Pande H, Waaler P E. Letter: $\beta$-hydroxy isovaleric aciduria and $\beta$-methyl. crotonylglycinuria. A new inborn error of metabolismLancet 1970; ii: 521-2.

2 Gompertz D, Draffan G H, Watts J L, Hull D. Biotin responsive $\beta$-methylcrotonylglycinuria. Lancet 1971 ; ii: 22-4.

3 Gompertz D, Bartlett K, Blair D, Stern C M M. Child with a defect in leucine metabolism associated with $\beta$ hydroxyisovaleric aciduria and $\beta$-methylcrotonylglycinuria. Arch Dis Child 1973; 48: 975-7.

4 Finnie M D A, Cottrall K, Seakins J W T, Snedden W. Massive excretion of 2-oxoglutaric acid and 3-hydroxyisovaleric acid in a patient with deficiency of 3-methylcrotonyl CoA carboxylase. Clin Chim Acta 1976; 73: 513-9.

5 Keeton B R, Moosa A. Organic aciduria. Treatable cause of floppy infant syndrome. Arch Dis Child 1976; 51: 636-8.

6 Roth K, Cohn R, Yandrasitz J, Preti G, Dodd P, Segal S. Beta-methylcrotonic aciduria associated with lactic acidosis. J Pediatr 1976; 88: 229-35. 
7 Cowan M J, Wara D W, Packman S, et al. Multiple biotin-dependent carboxylase deficiencies associated with defects in T-cell and B-cell immunity. Lancet 1979; ii: $115-8$.

8 Charles B, Hosking G, Green A, Pollitt R, Bartlett K, Taitz L S. Biotin-responsive alopecia and developmental regression. Lancet 1979; ii: 118-20.

9 Lehnert W, Niederhoff H, Junker A, Saule H, Frasch W. A case of biotin responsive 3-methylcrotonylglycin- and 3-hydroxyisovaleric aciduria. Eur J Pediatr 1979; 132: 107-14.

10 Finnie M D A, Ersser R S, Seakins J W T. The occurrence and identification of o- hydroxyhippuric acid (salicyluric acid) in the urine of sick children. Clin Chim Acta 1976; 70: $171-8$.

11 Gompertz D, Storrs C N, Bau D C K, Peters T J, Hughes E A. Localisation of enzymic defect in propionicacidaemia. Lancet 1970 ; i: 1140-3.

12 Gompertz D, Goodey P A, Bartlett K. Evidence for the enzymic defect in $\beta$-methylcrotonylglycinuria. FEBS Lett 1973; 32: 13-4.

13 Lowry O H, Rosebrough N J, Farr A L, Randall R J. Protein measurement with Folin phenol reagent. $J$ Biol Chem 1951; 193: 265-75.

14 Landaas S. Increased urinary excretion of 3-hydroxyisovaleric acid in patients with ketoacidosis. Clin Chim Acta 1974; 54: 39-46.

15 Levy H L, Erickson A M, Lott I T, Kuertz D J. Isovaleric acidemia: results of family study and dietary treatment. Pediatrics 1973; 52: 83-94.

16 Faull K F, Bolton P D, Halpern B, Hammond J, Danks D M. The urinary organic acid profile associated with 3-hydroxy-3-methylglutaric aciduria. Clin Chim Acta 1976; 73: 553-9.
17 Leonard J V, Seakins J W T, Griffin N K. Letter: $\beta$ hydroxy- $\beta$-methylglutaricaciduria presenting as Reye's syndrome. Lancet 1979 ; i: 680.

18 Scott D. Clinical biotin deficiency ('egg white injury'). Acta Med Scand 1958; 162: 69-70.

19 Robinson F A. The vitamin co-factors of enzyme systems. Oxford: Pergamon, 1966.

20 Bartlett $\mathrm{K}$, Ng H, Leonard $\mathrm{J} \mathrm{V}$. A combined defect of three mitochondrial carboxylases presenting as biotin responsive 3-methylcrotonylglycinuria and 3-hydroxyisovaleric aciduria. Clin Chim Acta 1980; 100: 183-6.

21 Munnich A, Saudubray J M, Coude F X, Charpentier C, Saurat J H, Frezal J. Letter: Fatty-acid-responsive alopecia in multiple carboxylase deficiency. Lancet 1980; i: $1080-1$.

22 Roth K S, Yang W, Foreman J W, Rothman R. Segal S. Holocarboxylase synthetase deficiency: a biotin responsive organic acidaemia. J Pediatr 1980; 96: 845-9.

23 Rasmussen K, Steffensen O, Østergaard P, Gregersen N, Christensen E, Kølvraa S. Selective IgA deficiency in sputum with normal concentrations of immunoglobulins in the serum and normal cellular immunity in a patient with multiple carboxylase deficiencies (3-methylcrotonylglycinuria) (abstract). J Inherited Metabol Dis 1980; in press.

Correspondence to Dr J V Leonard, Department of Child Health, Institute of Child Health, 30 Guilford Street, London WCIN 1EH.

Received 5 February 1980

The following articles will appear in future issues of this journal:

Primary amoebic meningoencephalitis A R R Cain, P F Wiley, Betty Brownell, and D C Warhurst

Proctoscopy in infancy with reference to its use in necrotising enterocolitis $T$ R Fenton, $J A$ Walker-Smith, and $D R$ Harvey

Collection of breath for hydrogen estimation $A J$ Gardiner, $M J$ Tarlow, I T Sutherland, and $H G$ Sammons

Isoimmune neonatal thrombocytopenic purpura P Galea, M J Patrick, and $K M$ Goel

Estimating the cots required for neonatal intensive care $H$ Simpson and $G$ Walker

Annotation: Bronchodilator drugs in childhood asthma $A$ D Milner 